\title{
Relasi Konseptual Oposisi Makna Sumbangan Korporasi Pada Partai Politik Dalam Semiotic Square
}

\author{
Tashya Panji Nugraha \\ Fakultas Syariah dan Hukum UIN Raden Intan \\ Jln. Endro Suratmin, Sukarame Bandar Lampung \\ grahapanji19@gmail.com
}

Received: 27 April 2019; Accepted: 24 Juli 2019; Published: 22 Agustus 2019

DOI: 10.20885/iustum.vol26.iss2.art4

\begin{abstract}
Legal language can be utilised as a means to manipulate interests. A specific approach is needed to identify the potential distortion behind the text of positive legal norms. This study applies a legal semiotics approach. Through the semiotic square model, the potential for distortion at the conceptual level can be brought up to the surface. The result of the interpretation shows that Article 35 paragraph (1) letter $c$ of Law Number 2 of 2011 on Political Parties has the potential to be a means for corporations to infiltrate their interests. The opposing conceptual relations of meanings that can come up include: the corporate contributions to political parties which can be used as a means to influence the economic policies that would only favour the corporations; demanding the regulations that only protect, facilitate and benefit corporate activities; as well as investment field for the corporations to request the licensing and project or tender facilities. In the end, political parties do not have the sovereignty, independency and integrity.
\end{abstract}

Keywords: Corporations; legal semiotics; political parties; semiotic square

\section{Abstrak}

Bahasa hukum dapat dimanfaatkan sebagai medium untuk memanipulasi kepentingan. Diperlukan pendekatan yang spesifik untuk mengidentifikasi potensi distorsi di balik teks norma hukum positif. Penelitian ini menggunakan pendekatan semiotika hukum. Melalui model semiotic square potensi distorsi pada tataran konseptual dapat dimunculkan. Hasil pemaknaan menunjukkan Pasal 35 ayat (1) huruf c Undang-Undang Nomor 2 Tahun 2011 tentang Partai Politik berpotensi untuk dijadikan medium bagi korporasi menyusupkan kepentingannya. Relasi konseptual oposisi makna yang dapat muncul diantaranya, sumbangan korporasi pada partai politik dapat dijadikan sarana untuk memengaruhi kebijakan ekonomi yang hanya berpihak pada korporasi. Menuntut regulasi yang hanya melindungi, memudahkan, dan menguntungkan kegiatan korporasi. Arena investasi bagi korporasi untuk meminta kemudahan perizinan dan proyek/tender. Partai politik pada akhirnya tidak memiliki kedaulatan, kemandirian, dan integritas.

Kata-kata Kunci: Semiotika hukum; semiotic square; korporasi; partai politik 


\section{Pendahuluan}

Pendekatan semiotika hukum awalnya dikembangkan oleh para eksponennya dari teori semiotika Willian Charles Sanders Peirce, Algirdas Julien Greimas, dan Jacques Marie Emile Lacan. ${ }^{1}$ Topik yang dianggap penting dalam semiotika hukum menurut Roberta Kevelson berkaitan dengan aturan hukum, keputusan hukum, prosedur hukum, moral, dan keadilan. ${ }^{2}$ Jan M. Broekman dan Larry Cata Backer menjelaskan kajian semiotika hukum berfokus pada makna tanda dan simbol dalam hukum. ${ }^{3}$ Bernard Jackson berpendapat bahwa semiotika hukum dapat dijadikan kritik radikal terhadap positivisme hukum. ${ }^{4}$

Paul Scholten dalam De Structuur Der Rechtswetenschap intinya menyatakan ada persamaan antara masalah hukum dan masalah bahasa. Bukan kebetulan apabila hukum terikat dalam bahasa. ${ }^{5}$ Mempelajari semiotika hukum berkaitan dengan kesadaran bahwa bahasa hukum memiliki makna tanda-tanda atau simbol penting di dalamnya. ${ }^{6}$ Kegiatan hukum hidup dalam bahasa hukum baik bagi pengemban hukum teoretis maupun praktis. ${ }^{7}$ Simbol bahasa memiliki makna nilai di dalamnya, substansi makna inilah yang menjadi esensi bahasa.

${ }^{1}$ Lihat Roberta Kavelson, Intoduction to The Firsh Round Table on Law and Semiotics. Roberta Kevelson (ed), Law and Semiotics, Volume 1, Plenum Press, New York and London, 1987, hlm. 2. Broekman dan Backer menyebutkan ke tiga orang tersebut sebagai Godfather semiotika. Lihat Jan M. Broekman and Lary Cata Backer, Lanyers Making Meaning The Semiotics of Law in Legal Education II, Springer Dordrecht Heidelberg, 2013, LondonNewYork, hlm. 33.

${ }^{2}$ Lihat Roberta Kavelson, The Law as a System of Signs, Plenum Press, New York 1988, hlm. 8.

${ }^{3}$ Lihat Jan M. Broekman and Lary Cata Backer, Lawyers Making Meaning..., Op. Cit., hlm. 8.

${ }^{4}$ Lihat Vadim Verenich, "The Semiotic Model of Legal Reasoning”, International Journal of Law, Language \& Discourse, 2012, hlm. 25-58. Pendapat ini dapat dipahami bahwa realitas hukum bukan hanya pada norma hukum yang dibahasakan ke dalam teks aturan hukum yang mengedepankan aspek kepastian semata, tetapi terdapat makna nilai dan simbol-simbol yang terakumulasi di dalamnya. Semiotika hukum dapat dimanfaatkan untuk mengkritisi apakah nilai-nilai kebenaran, keteraturan, keadilan, kemanfaatan dan nilai-nilai lain yang terkandung dalam makna hukum menjelma dalam kenyataan dan memberikan manfaat. Hukum merupakan bagian dari tanda-tanda dalam kehidupan manusia, sehingga dalam memaknai hakikatnya diperlukan refleksi yang komprehensif. Norma hukum positif tidak dapat mewujudkan esensinya tanpa masuk ke dalam makna yang ada di baliknya berdampingan dengan realitas sosial pada tataran empiris.

5 Paul Scholten, De Structuur Der Rechtswetenschap, Konninklijke Nederlansche Akademie, van Wetenschappen, Afdeeling Letterkunde, 17 Maret 1942. Terjemahan. B. Arief Sidharta, Struktur Ilmu Hukum, Alumni, Bandung, 2013, hlm. 39.

${ }^{6}$ Jan M. Broekman and Lary Cata Backer, Lawyers Making Meaning..., Op. Cit., hlm. 16. Broekman dan Backer menjelaskan hal ini berkaitan dengan pentingnya kesadaran bagi mahasiswa hukum dan pengacara, bahwa dalam bahasa hukum terdapat tanda-tanda, simbol, dan makna.

${ }^{7}$ Dikemukakan bahwa simbolisme bahasa yang mempunyai makna hukum, maksudnya nilai-nilai hukum, asas-asas hukum, kaidah hukum dan sikap tindak hukum, hanya dapat dimengerti oleh manusia dengan melalui peranan bahasa yang menjelaskan sifat abstrak makna hukum dari padanya. Lihat Soetandyo Wignjosoebroto, Hukum, Paradigma., Metode dan Dinamika Masalabnya, ELSAM dan HUMA Press, Jakarta, 2002, hlm. 225. Cakupan bahasa hukum berwujud produk hukum tertulis maupun keterampilan penggunaan bahasa dalam profesi hukum. Dalam Ihkwan M. Said, “Perspektif Masalah Kebahasaan Bahasa Indonesia di Bidang Hukum”, Makalah Proseding 
Teks norma hukum positif merupakan simbol yang ditujukan untuk merumuskan beragam ide berisi nilai-nilai hukum. ${ }^{8}$ Hukum dalam realitasnya dapat terdistorsi, bertegangan, dan membawakan unsur ketidakbenaran. ${ }^{9}$ Realitas normatif dapat merefleksikan cita hukum yang menjauh dari tujuannya, bertegangan, bersifat distorsif, dan penuh kepura-puraan, tetapi direprensetasikan sebagai realitas dan konsep kebenaran hukum.

Bahasa yang beroperasi di balik teks norma hukum positif ternyata dapat dijadikan sarana untuk memanipulai kepentingan. Hukum dalam kondisi tertentu dapat menjadi sarana untuk menjastifikasi kesalahan menjadi suatu kebenaran. ${ }^{10}$ Hukum dapat dijadikan sebagai alat untuk mendominasi kekuasaan. ${ }^{11}$ Hukum dapat dijadikan alat pembenar untuk sebuah kejahatan tersembunyi. Hukum dapat dijadikan sarana untuk mengkriminalisasi. Akhirnya realitas bahasa hukum yang diwujudkan dalam teks norma hukum positif menjadi sebentuk topeng kebenaran. Hal semacam ini memunculkan situasi krisis dalam makna hukum. ${ }^{12}$ Hukum yang tampil tidak lagi merepresentasikan atau mencerminkan makna nilai hukum yang sesungguhnya sebagaimana diilustrasikan dalam Ragaan 1 berikut.

Seminar Bersama UNHAS, Makasar, 6-8 November 2006, hlm.2. Bahasa hukum berperan dalam aspek sosial, ekonomi, politik, agama, kesenian, dan keilmuan.

8 Simbol-simbol merujuk pada nilai-nilai dapat diungkapkan melalui image (citra) dengan demikian keterkaitan simbol, nilai, dan bahasa sangat erat. Dalam Rofik Suhud, Ekspresi Politik Muslim, Mizan, Bandung, 1998, hlm. 20. Manusia dapat merubah hasil pengalaman inderawi menjadi simbol-simbol. Simbol-simbol ini dapat digunakan untuk menunjuk pada simbol yang lain seperti konsepsi tujuan, nilai, dan cita. Bandingkan dengan Alex Sobur, Analisis Teks Media, Remaja Rosdakarya, Bandung, 2004, hlm. 164 dan 176. Nilai adalah sesuatu yang dijunjung tinggi, sesuatu yang memberi makna kepada hidup yang memberi kepada hidup itu titik tolak, isi, dan tujuan. Menurut Steeman, nilai sesuatu yang dipandang cukup mulia untuk diperhatikan, dan menuntut kesetiaan dan ketaatan. Theodore M. Steeman, "Religious and National Integration", Desertation Harvard University, 1973, dalam Yovita A. Mangesti dan Bernard L Tanya, Moralitas Hukum, Genta Publishing, Bantul-Yogyakarta, 2014, hlm. 16.

${ }_{9}^{9}$ Makna simbolik merupakan sesuatu yang menyatakan suatu hal atau mengandung maksud tertentu atau sesuatu yang mewakili sesuatu yang lain tidak dapat diindera tetapi melekat pada objeknya atau makna substansi di balik entitas inderawi.

10 Tanda diekspresikan dan dijadikan alat mengekspresikan, tanda diartikulasikan dan tanda dijadikan instrumen justifikasi. Marcus Lukman, "Semiotika Reformasi Hukum Res Republika, Res Konstitusi, dan Res Ketuhanan”, Pusat Pengkajian Hukum dan Pembangunan, Jurnal Perpektif Vol. 3, No. 3, edisi Juli, Tahun 1998, hlm. 9

11 Baca Suharyo, Surono, Mujid F. Amin, "Bahasa dan Kekuasaan: Antara Pertarungan Wacana dan Perebutan Kekuasaan (Studi Kasus Perilaku Politisi di Media Massa”, Jurnal HUMANIKA Vol. 19 No. 1 Fakultas Ilmu Budaya Universitas Diponegoro Semarang, 2014, hlm. 43. Baca Gramsci, Selection form Prison Notebooks, Lawrence and Wishart, London, 1991, hlm. 195.

12 Bandingkan Antonisus Cahyadi, Hukum sebagai Teks:Penanda yang Kosong, dalam Antonisus Cahyadi dan Donny Danardono (ed), Sosiologi Hukum dalam Perubahan, Obor Indonesia Press, Jakarta, 2009, hlm. 291. Sudjito, Ilmu Hukum Holistik: Studi untuk. Memahami Kompleksitas, dan Pengaturan Pengelolaan Irigasi, Gadjah Mada University Press, Yogyakarta, 2014, hlm. 110-111. 


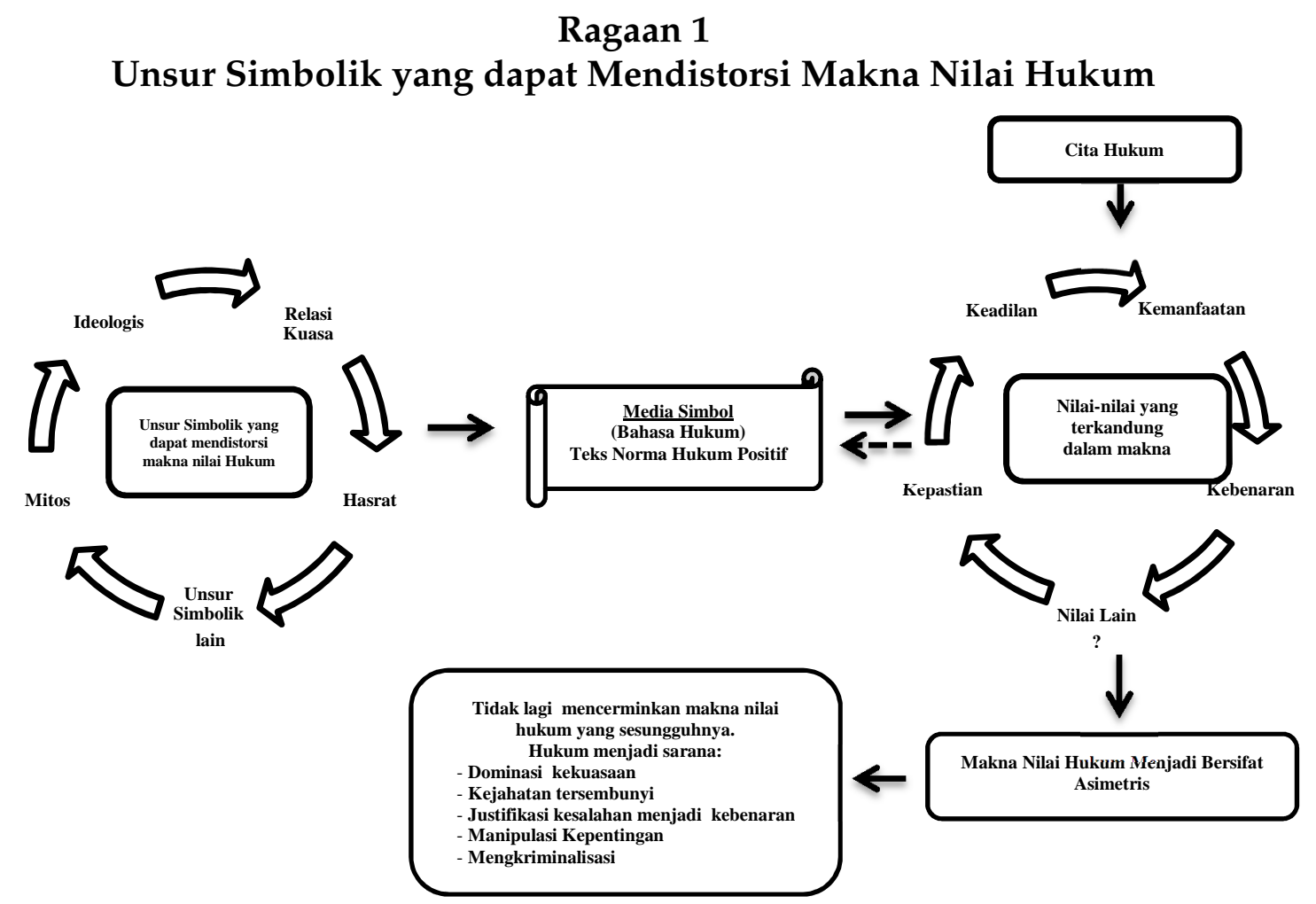

Berdasarkan ragaan di atas menunjukkan adanya kebutuhan untuk menerapkan model kajian yang spesifik. Makna-makna simbolik dan intrinsik di balik bahasa dapat diungkap dengan menggali objek hukum sebagai tanda. Diperlukan pembacaan hukum melalui pendekatan semiotika. Ilmu yang mengkaji makna tanda secara mendalam baik itu yang bersifat konkret, abstrak, verbal, dan nonverbal. Hukum hadir dan ditafsirkan sebagai entitas tanda yang memiliki kandungan makna di baliknya. ${ }^{13}$ Model semiotic square dapat digunakan untuk menjelaskan dimensi intrinsik di balik teks norma hukum positif. Pengemban hukum teoretis maupun praktis dapat memanfaatkannya untuk mengungkap relasi konseptual oposisi makna yang mungkin beroperasi di balik teks norma hukum positif. ${ }^{14}$

Prinsip demokrasi yang disandarkan pada nilai kebebasan dan kedudukan setara tidak hanya dimaknai dalam aspek untuk dapat memilih dan dipilih

13 Bandingkan Sophie Cacciaguidi, Fahy, Annabelle Mooney, "The Promise of Legal Semiotics", International Journal Semiotics of Law, Springer, 26 Agustus 2009, hlm. 382.

14 Pengemban hukum teoretis dapat menggunakan pendekatan model semiotic square sebagai alat analisis untuk mengkritisi dan mengevaluasi beragam produk peraturan perundang-undangan. Mengungkap dan menjelaskan pada tataran konseptual-teoretis beragam muatan kepentingan yang mungkin dibenamkan di balik teks norma hukum positif. Pendekatan model semiotiq square dalam perumusan peraturan perundang-undangan bagi pengemban hukum praktis (khususnya pembentuk hukum) dapat difungsikan untuk meminimalisir celah-celah pada produk hukum yang dihasilkannya, sehingga tidak mudah dimanfaatkan oleh kepentingan-kepentingan tertentu yang dapat mengakibatkan ketidakadilan. 
semata. ${ }^{15}$ Makna nilai kebebasan dan kesetaraan dapat dimaknai dalam bentuk partisipasi dan kontribusi seluruh komponen bangsa secara lebih luas. Salah satunya dengan memberikan sumbangan uang, barang, dan/jasa kepada partai politik dengan menjunjung tinggi hukum atau peraturan. Kontestasi politik yang membutuhkan biaya tinggi dalam proses demokrasi dapat membuka peluang untuk dimanfaatkan oleh kelompok tertentu. Fasilitas demokrasi digunakan sebagai sarana berinvestasi politik untuk meraup keuntungan darinya. ${ }^{16}$ Kata "sumbangan" yang memiliki makna konotasi positif dapat menjadi simbol efektif untuk membenamkan kepentingan yang ada di baliknya.

Kehebatan makna nilai kebebasan dan kesetaraan untuk berkontribusi dalam proses demokrasi tetap harus diwaspadai dengan mempertimbangakan aspek kerentanannya. Kepentingan tertentu dapat masuk dan memanfaatkan kehebatan makna tersebut. Akhirnya proses demokrasi yang tampil menjadi tidak sehat dan mengakibatkan ketidakadilan. Pasal 35 ayat (1) huruf c Undang-Undang Nomor 2 Tahun 2011 tentang Partai Politik, menentukan bahwa sumber keuangan partai politik salah satunya dapat bersumber dari sumbangan perusahaan dan/atau badan usaha (korporasi). Model semiotic square akan difungsikan untuk menggali secara lebih dalam mengenai relasi konseptual oposisi makna kata "sumbangan" yang beroperasi di balik teks tersebut. Produk hukum pada tataran normatif memang membutuhkan pengkajian yang mendalam. Makna nilai kepastian hukum idealnya harus beriringan dengan nilai keadilan dan kemanfaatan.

\section{Rumusan Masalah}

Berdasarkan uraian yang disajikan di atas, rumusan masalah dalam penelitian ini adalah, bagaimana relasi konseptual oposisi makna kata "sumbangan" korporasi pada partai politik dalam model semiotic square?

${ }^{15}$ Demokrasi pada hakikatnya menghendaki kesamaan dan kesetaraan hak-hak dalam menjalankan ataupun berkonstribusi menurut peran politiknya masing dalam konteks proses demokrasi. Refleksi nilai keteraan ini merupakan realitas penting dalam proses demokrasi. Baca juga David Beetham dan Kevin Boyle, Introducing Democracy: 80 Questionse Answers, terjemahan Bern Hidayat, Demokrasi: 80 Tanya Jawab, Kanisius, Yogyakarta, 1995, hlm. 21-22.

16 Bentuk manipulatif yang dapat dilakukan baik itu oleh korporasi milik warga negara Indonesia (lokal/domestik) atau Korporasi milik asing. 


\section{Tujuan Penelitian}

Sejalan dengan identifikasi masalah di atas, maka tujuan penelitian ini untuk mengungkap relasi konseptual oposisi makna kata "sumbangan" korporasi pada partai politik melalui model semiotic square.

\section{Metode Penelitian}

Jenis penelitian ini termasuk dalam tradisi kajian hukum nondoktrinal. ${ }^{17}$ Penelitian menggunakan pendekatan semiotika hukum. Hukum di konsepkan sebagai simbol yang penuh kandungan makna. ${ }^{18}$ Objek yang ditempatkan untuk dikaji adalah teks norma hukum positif. ${ }^{19}$ Mencermati apa yang disampaikan oleh Norman K. Denzim and Yvonna S. Lincoln bahwa:

17 Semiotika hukum merupakan kajian yang relatif baru dalam ilmu hukum. Selain penelitian hukum nondoktrinal yang bersifat empiris berkembang pula penelitian nondoktrinal yang bersifat simbolik. Realitas adalah bagian dari alam makna atau alam simbolik. Kelompok teoretisi yang berada dalam tradisi ini berpandangan bahwa realitas kehidupan (hukum) tidak semata muncul secara empiris. Realitas tidak hanya menampak pada wujud perilaku yang terpola (terstruktur) secara objektif, apalagi normatif sehingga dapat diukur. Realitas kehidupan (hukum) dapat eksis dalam tataran alam makna (simbolik) karena itu akan sulit ditangkap apabila hanya mengandalkan bentuk permukaannya saja. Bandingkan Sulistyowati Irianto dan Shidarta (ed), Metode Penelitian Hukum: Konstelasi dan Refleksi, yayasan Obor, Jakarta, hlm. 132, 135-138. Cermati Soetandyo Wignjosoebroto, Hukum Paradigma, Metode dan Dinamika Masalahnya, 2002, Elsam dan Huma, Jakarta, hlm. 147-148. Lihat Soetandyo wignjosoebroto, Konsep Hukum dan Ilmu Sosial: Perbedaan Ancangan Konsepsional dan Konsekuensi Metodenya, Makalah Penalaran Metodologi Penelitian Hukum di Fakultas Hukum Universitas Hasanuddin, Makasar, Februari 1994, hlm 4-5. Bandingkan M Syamsudin, Konstruksi Budaya Hukum: Berbasis Hukum Progesif, Kencana Prenada Media Group, Jakarta, 2012, hlm. 17. Pendekatan interaksionis simbolik dan semiotika hukum dapat ditempatkan dalam tradisi penelitian hukum nondoktrinal. Penelitian semiotika hukum mengidentifikasi dimensi intrinsik di balik entitas inderawi atau menelisik kandungan makna di balik yang tampak dipermukaan.

${ }^{18}$ Hukum adalah gejala kenyataan masyarakat yang majemuk, mempunyai banyak aspek, dimensi, dan bersifat multi faset. Hukum berakar dan terbentuk dalam proses interaksi berbagai aspek kemasyarakatan (politik, ekonomi, sosial, budaya, teknologi, keagamaan, dan sebagainya), dibentuk dan ikut membentuk tatanan kemasyarakatan dengan berbagai sifatnya, namun sekaligus ikut menentukan bentuk dan sifat-sifat masyarakat itu sendiri. Dalam dinamikanya hukum itu dikondisikan dan mengkondisikan masyarakat. Baca B. Arief Sidharta, Refleksi tentang Struktur Ilmu Hukum: Sebuah Penelitian tentang Fundasi Kefilsafatan dan Sifat Keilmuan Ilmu Hukum sebagai Landasan Pengembangan Ilmu Hukum Nasional Indonesia, Mandar Maju, Bandung, 2000, hlm. 116.

19 Penelitian hukum doktrinal (normatif) dalam positivisme hukum menempatkan sistem norma sebagai pusat kajiannya. Penelitian jenis ini biasanya dilakukan untuk memberikan argumentasi hukum sebagai dasar penentu apakah suatu peristiwa sudah sesuai dengan aturannya. Mendayagunakan silogisme deduktif untuk menemukan jawaban terhadap objek masalahnya. Norma positif didudukan sebagai premis mayor sehingga menjadi penentu konklusi yang dihasilkan dalam konstruksi silogisme deduktif. Cermati Soetandyo Wignjosoebroto, Hukum Paradigma, Metode dan Dinamika Masalabnya, Loc. Cit. Lihat Mukti Fazar dan Yulianto, Dualisme Penelitian Hukum: Normatif dan Empiris, Pustaka Pelajar, Yogyakarta, 2015, hlm. 34-36. Bandingkan Shidarta, Hukum Penalaran dan Penalaran Hukum, Genta Publishing, Yogyakarta, 2013, hlm. 197-201. Cermati Soerjono Soekamto dan Sri Mamuji, Penelitian Hukum Normatif: Suatu Tinjauan Singkat, Raja Gravindo Persada, Jakarta, 1995, hlm. 15. Bandingkan Peter Mahmud Marzuki, Penelitian Hukum, Kencana Penadamedia Group, Jakarta, 2005, hlm. 35. Penelitian nondoktrinal dalam pendekatan semiotika hukum salah satunya digunakan untuk mengkritisi premis mayor tersebut. Kandungan muatan ideologis, makna nilai, dan unsur-unsur simbolik lain merupakan bagian yang diungkap dalam proses analisisnya. Sistem norma dapat menjadi salah satu objek penelitian dalam kajian semiotika hukum. Namun demikian, uraian analisisnya memiliki titik tekan yang khas (berbeda) dengan peneleitian normatif, yaitu menelisik kandungan makna di balik entitas inderawi (teks norma hukum positif) sebagaimana yang tersaji dalam penelitian ini. 
"Succesive waves of epistemological theorizing move a cross these eight moments, The traditional period is associated with the positivist, foundational paradigm. The modernist or golden and blurred genres moments are connected to the appearance of postpositivist argument, at the same time, variety of new interpretive, qualitative perspectives were taken up, including hermeneutics, structuralism, semiotics, phenomenology, cultural studies, and feminism: In the blurred genres phase, the hermeneutics became central resources for critical interpretative theory, and the qualitative reseach project broadly conceived...".20

Pendekatan semiotika hukum bersifat dialogis (dialogistic mode of reasoning) yang menyediakan ruang inheren bagi karakter, sumber, batasan, dan validitas kebenaran hukum termasuk bahan hukum ketika pengungkapan kandungan makna (analisis) dilakukan. Kebenaran hukum tidak semata disandarkan pada kemampuan rasio (abstraksi teoretis-normatif) semata tetapi dapat melibatkan kebenaran yang mengacu pada aspek fakta pada tataran empiris atau aspek kebenaran dalam tataran intuitif-transendental. ${ }^{21}$ Disesuaikan dengan titik tekan masalah serta alur pengungkapan makna yang akan dikaji oleh peneliti.

Penelitian ini bersifat deskriptif analitis melalui studi kepustakaan dengan memanfaatkan data sekunder. Metode analisis data menggunakan interpretasi yang sejalan dengan pendekatan semiotika itu sendiri sebagai ilmu untuk menafsirkan tanda. Melalui pendekatan semiotika hukum (model semiotic square)

${ }^{20}$ Norman K. Denzim and Yvonna S. Lincoln, Introduction The Discipline and Practice of Qualitative Research, Dalam Norman K. Denzim and Yvonna S. Lincoln, ed., The SAGE Handbook of Qualitative Research: Fifth Edition, Sage Publication, London, 2018, hlm. 3.

21 Pendekatan semiotika hukum berada dalam lingkup tradisi kajian hukum nondoktrinal. Pendekatan semiotika melihat hukum sebagai salah satu sistem tanda seperti produk atau lembaga sosial lainnya, misalnya bahasa, ekonomi, politik, keluarga, dan seterusnya. Pendekatan semiotika menghadirkan komunikasi intersistemik (intersystemic) antar metode, disiplin dan subsistem budaya. Hukum tidak dilihat sebagai sesuatu yang otonom. Pendekatan semiotika dikelompokan juga sebagai salah satu bagian dalam penelitian kualitatif filsafat. Konsekuensi metodologis pendekatan semiotika hukum yang bersifat dialogis adalah menghindari perangkap sekat-sekat metodologis. Termasuk diantaranya dapat memanfaatkan beragam bahan hukum dalam proses analisisnya baik data primer maupun sekunder. Menggunakan salah satunya atau mengkombinasikan keduanya disesuaikan dengan kebutuhan si peneliti. Cermati Roberta Kevelson, The Law as a System of Signs, Ibid, hlm. 10. Baca Roberta Kavelson, "Semiotics and Methods of Legal Inquiry: Interpretation and Discovery in Law from the Perspective of Peirce's Speculative Rhetoric", Indiana Journal Law, Vol. 61: Iss. 3, Article 3, Indiana University, 1986, hlm. 354-356. Cermati Jan M. Broekman and Lary Cata Backer, Lanyers Making Meaning The Semiotics of Law in Legal Education II, Op. Cit., hlm. 117. Lihat J. M. Bochenski, The Method of Comtemporary Thought, translate by Peter Caws, Springer, Netherlands, 1965, hlm.31-32. Lihat Malcolm Williams and Tim May, Introduction to The Philosophy of Social Research, London, UCL Press, 1996, hlm. 11 and 136. Lihat Kaelan M.S, Metode Penelitian Kualitatif Bidang Filsafat; Paradigma bagi Pengembangan Penelitian Interdisipliner Bidang Filsafat, Budaya, Semiotika, Sastra, Hukum, dan Seni, Paradigma, Yogyakarta, 2005, hlm. 28. Irmayanti M. Budiyanto, Realitas dan Objektivitas: Refleksi Kritis Atas Cara Kerja Ilmiah, Wedya Sastra, 2002, Jakarta, hlm. 82. Lihat Anthon F. Susanto, Dekonstruksi Hukum: Eksplorasi Teks dan Model Pembacaan, Genta Publishing, 2010, Yogyakarta, hlm. 107-108. 
akan dilakukan telaah kritis terhadap Pasal 35 ayat (1) huruf c Undang-Undang Nomor 2 Tahun 2011 tentang Partai Politik.

\section{Hasil Penelitian dan Pembahasan}

Performatif bahasa yang menjelma ke dalam teks norma hukum positif sebagai unit terorganisir dapat dicermati sebagai suatu narasi. Menghadirkan makna-makna tertentu untuk dibaca, diartikan, dan digali kembali maknanya. ${ }^{22}$ Model Semiotic square merupakan perangkat analisis yang berada pada tataran deep semio-narrative level. Model Semiotic square digunakan untuk mengidentifikasi kandungan makna melalui sistem oposisi. ${ }^{23}$

Model semiotic Square dirancang sebagai jaringan konseptual dan representasi visual bagi artikulasi logis dari suatu bentuk oposisional. ${ }^{24}$ Model semiotic Square digunakan untuk memperbaiki analisis oposisi dengan meningkatkan jumlah kelas oposisi dari dua dapat menjadi empat, delapan, bahkan sepuluh. ${ }^{25}$ Daniel Chander menyampaikan bahwa model semiotic square merupakan salah satu teknik analitis

22 Performatif bahasa merupakan bahasa yang digunakan dalam konteks-konteks tertentu yang artinya berasal dari penggunaan untuk menjalankan arti (aktivitas) yang sedang dijelaskan atau terdapat dalam kegiatan mengucapkan. Lihat Jan M. Broekman and Larry Catá Backer, Reading Semiotics, Jan M. Broekman and Larry Catá Backer (ed), Signs In Law-A SourceBook. The Semiotics of Law in Legal Education III, Springer International Publishing Switzerland, Heidelberg New York Dordrecht London, 2015, hlm. 6-8.

${ }^{23}$ Model semiotic square menjadi perangkat analisis yang diadaptasi masuk ke dalam kajian hukum oleh para eksponennya, selain Ellswoth beberapa diantanya dapat dilihat dalam tulisan Michelle L. Wirth, Semiotics of Parenthood in Legal Perspective: Using Semiotic Tools to Deconstruct Legal Determinations of Who Holds Parenthood Obligations and Privileges, Meghann L. Garrett, Trademarks as a System of Signs: A Semiotician's Look at Trademark Law, Nathan S. Harvill, The Semiotics of Public Use: Use the Purpose by Which All May Benefit, dalam Jan M. Broekman Francis J. Mootz III (ed), The Semiotics of Law in Legal Education, ibid, 157-246. Larry Catá Backer, A View on A. J. Greimas's Essay The Semiotic Analysis of a Legal Discourse: Commercial Laws That Govern Companies and Groups of Companies, dalam Jan M. Broekman and Lary Cata Backer, Lawyers Making Meaning..., Op. Cit., hlm. 129-140.

${ }^{24}$ Semiotika Greimas merupakan metode atau alat analisis yang digunakan untuk menggali makna suatu narasi. Struktur narasi diandaikan mendasari semua wacana tidak hanya wacana cerita klasik tetapi dapat berupa wacana politik, sosiologis, hukum dan lain-lain. Martin Bronwen dan Felizitas Ringham berpadangan prinsip dasar analisis teks dalam semiotika Greimas dimulai dengan mengamati bahasa dan struktur teks lalu menjelaskan bagaimana makna dikontruksi. Analisis yang mengemukakan tentang gagasan tingkat makna permukaan dan makna dalam. Makna hadir dalam beberapa tahapan sehingga teks harus dicermati pada tingkat-tingkat kedalamannya. Bronwen Martin and Felizitas Ringham, Dictionary of Semiotics, Cassel, London and New York, 2000, hlm. 7-8. Tingkatan struktur makna narasi (semantic structure narrative) dibagi ke dalam discursive structure, semio-narative structure, dan teks itu sendiri sebagai bentuk fisiknya. Semio-narative structures dibagi kembali ke dalam surface level semionarrative structures (struktur makna permukaan) dan deep Level semio-narrative structure (struktur makna dalam). Model semiotic square berada pada level deep semio-narrative structure. A. J. Greimas and J. Courtés, Semiotics and Language: An Analytical Dictionary, trans. Larry Crist, Daniel Patte, James Lee, Edward McMahon II, Gary Phillips, and Michael Rengstorf, Indiana University Press, Bloomington, 1982, hlm. 133. Lihat Ronald Schleifer, A.J Greimas and The Nature Meaning: Lingustics, Semiotics, and Discourse theory, Croom Helm-Roudledge, Australia, 1987, hlm. 86.

${ }^{25}$ Baca Hebert Loui Herberts, Tool for Texts and Image Analysis An Introduction to Applied Semiotics, Julie Tabler, Departement de Letter Universitie du Quebec, 2018, hlm. 39. "The semiotic square is a visual presentation of the elementary structure of meaning. Articulating the relationships of contrariety (opposition), contradiction and implication, it is the logical expression of any semantic category. Bronwen Martin and Felizitas Ringham, Dictionary of Semiotics...”, Op. Cit., hlm. 12. 
untuk memetakan oposisi dan persimpangan (intersections) makna yang berlangsung dalam teks dan praktik budaya. ${ }^{26}$ Model semiotic square dapat dicermati dalam Ragaan 2 berikut.

\section{Ragaan 2}

Term and Metaterm dalam Semiotic Square ${ }^{27}$

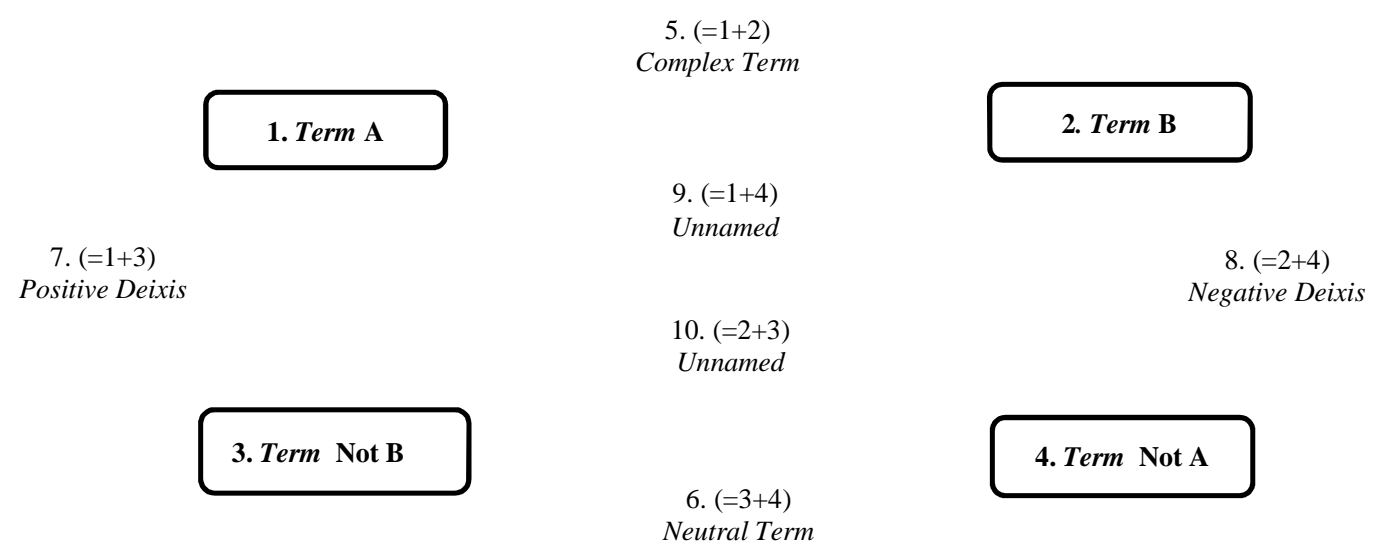

Representasi visual tersebut menunjukan bahwa terdapat 4 (empat) term oposisi dasar yang membentuk semiotic square yaitu term A, B, Not B dan Not A (angka 1 sampai 4). Angka 5 sampai dengan angka 10 merupakan metaterm yang dapat menunjukan kemungkinan kombinasi dari masing-masing dua term dasarnya, termasuk nama istilah dari hubungan keduanya. ${ }^{28}$ Relasi dasar dari masing-masing term dapat dilihat dalam Ragaan 3 berikut.

Ragaan 3

Term Relations Semiotic Square

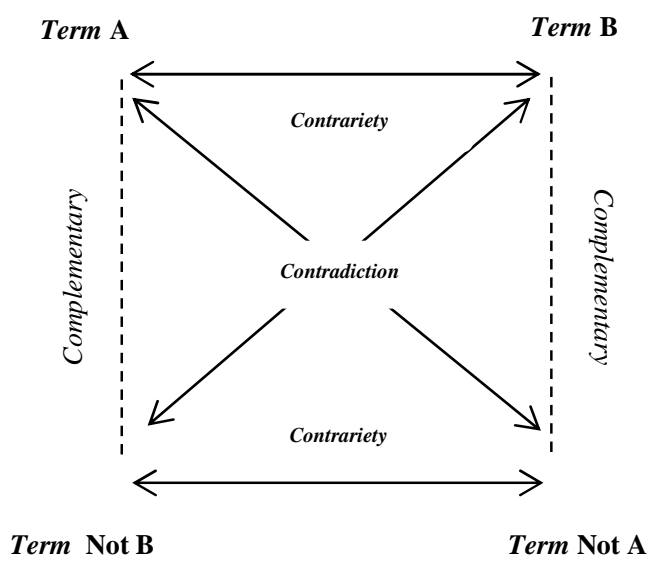

${ }^{26}$ Daniel Chandler, Semiotics: The Basic, Second Edition, Routledge, 2007, London-New York, hlm. 106.

${ }^{27}$ Louis Hebert, Tool for Texts and Image Analysis, Loc.Cit.

${ }^{28}$ Ibid., hlm. 40. 
Tiga relasi dasar yang terbentuk adalah hubungan antara term A dengan term B dan term Not A dengan term Not B. ${ }^{29}$ Relasi tersebut dinamakan dengan contrariery atau pertentangan. Hubungan antara term A dengan term Not A dan term B dengan term Not B merupakan kontradiksi (contradiction). Hubungan antara term Not B dengan term A dan term Not A dengan term B disebut dengan hubungan implikasi atau saling melengkapi (complementary). ${ }^{30}$ Berikutnya mengenai tindakan operasi dari semiotic square dapat divisualisasikan dalam Ragaan 4 berikut.

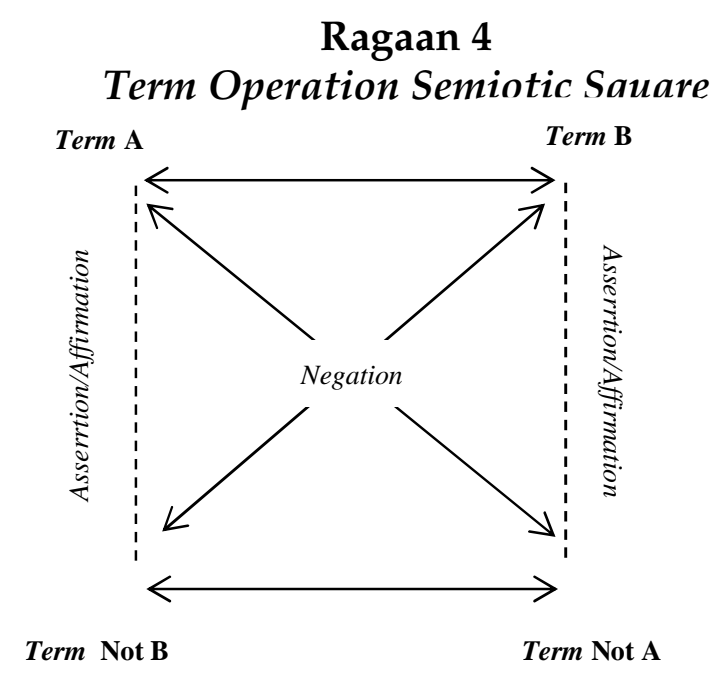

Operasi atau transformasi dasar dalam semiotic square terjadi melalui negasi (negation) dan penegasan (assertion/affirmation). Operasi negasi ditunjukkan oleh term A dengan term Not A dan term B dengan term Not B. Operasi kedua yaitu penegasan (assertion) atau persetujuan (affirmation) ditunjukan oleh term Not B dengan term Not A dan term Not A dengan term Not A. ${ }^{31}$ Chander menyampaikan bahwa model semiotic square dapat digunakan untuk mengidentifikasi tema tersembunyi yang mendasari suatu teks. Penggunaan istilah harus dimaknai secara politis. ${ }^{32}$

Pasal 35 ayat (1) huruf c Undang-Undang Nomor 2 Tahun 2011 tentang Partai Politik yang menyatakan bahwa sumbangan sebagaimana dimaksud dalam Pasal 34

${ }^{29}$ Hubungan antara term Not A dengan term Not B dapat juga dilihat sebagai hubungan subcontraries atau neutral term. Cermati Louis Hebert, Tool for Texts and Image Analysis, Ibid., hlm. 28, 29 dan 41.

${ }^{30}$ Bandingkan Daniel Chandler, Semiotics: The Basic, Second Edition, Routledge, 2007, London and New York, hlm. 106-107. Winfried Noth, Handbook of Semiotic, Indiana University Press, Bloominton \& Indianapolis, 1990, hlm. 318-319.

31 Ibid., hlm. 40.

32 Baca Winfried Noth, Handbook of Semiotic..., Op. Cit., hlm. 108. 
ayat (1) huruf $b$ yang diterima Partai Politik berasal dari perusahaan dan/atau badan usaha, paling banyak senilai Rp7.500.000.000,00 (tujuh miliar lima ratus juta rupiah) per perusahaan dan/atau badan usaha dalam waktu 1 (satu) tahun anggaran. ${ }^{33}$ Pasal 35 ayat (2) kemudian menyatakan bahwa, sumbangan sebagaimana dimaksud pada ayat (1) didasarkan pada prinsip kejujuran, sukarela, keadilan, terbuka, tanggung jawab, serta kedaulatan dan kemandirian Partai Politik.

Kata "sumbangan" atau donasi atau derma, dalam bahasa Inggris disebut donation dan dalam bahasa Latin disebut donum. Pemberian yang secara umum bersifat materi maupun non materi. Pemberian ini mempunyai sifat sukarela tanpa adanya imbalan untuk mendapatkan keuntungan. Ada dua makna semantik kunci dalam kata sumbangan yaitu unsur sukarela dan tidak untuk mendapatkan balas jasa (imbalan). ${ }^{34}$ Sukarela sejatinya memiliki makna nilai yang luhur. Kepentingan pribadi atau golongan mendapatkan pengabaian dalam makna sukarela. Lebih mengedepankan pada kepentingan sesama manusia atau kemanusiaan.

Makna tanpa mengharapkan balas jasa (imbalan) hadir secara bersamaan dalam semangat pengorbanan dan ketulusan. Terdapat kandungan makna yang melampaui entitas duniawi dan menjangkau dimensi nilai spriritual. Sumbangan yang berasal dari korporasi kemudian dirangkaikan dengan prinsip-prinsip yang disandarkan pada makna nilai kejujuran, keadilan, terbuka, sukarela, tanggung jawab, serta kedaulatan, dan kemandirian partai politik. Sumbangan yang berasal dari korporasi kepada partai politik dituntun oleh nilai moral demokrasi. ${ }^{35}$

33 Pasal 34 ayat (1) Undang-Undang No. 2 Tahun 2011 tentang Partai Politik menyatakan bahwa, Keuangan Partai Politik bersumber dari: a. Iuran anggota, b. Sumbangan yang sab menurut bukum, dan c. Bantuan keuangan dari Anggaran Pendapatan dan Belanja Negara/ Anggaran Pendapatan dan Belanja Daerah. Lihat Peraturan Pemerintah No. 1 tahun 2018 tentang Bantuan Keuangan Partai Politik. Tiga alternatif pendanaan partai sebagaimana ini dipraktikkan oleh negara-negara demokrasi di dunia saat ini. Torang Rudolf Efendi Manurung, "Perkembangan Politik Hukum Pertanggungjawaban Partai Politik dalam Bantuan Pengelolaan Bantuan Negara Pasca Reformasi”, Jurnal Yustisia Vol.19, Januari-April, 2015, hlm. 119.

${ }^{34}$ Sumbangan dapat dimaknai pemberian sebagai bantuan dengan sukarela. Sukarela dapat dimaknai dengan kemauan sendiri dengan rela hati atau atas kehendak sendiri (tidak karena diwajibkan). Sukarela dapat dimaknai dengan kemauan sendiri dengan rela hati atau atas kehendak sendiri. https://kbbi.web.id, diakses pada 27 Juli 2018 .

${ }^{35}$ Demokrasi dapat dikatakan bergerak dalam irisan di antara dua dimensi yaitu kekuasaan dan etika. Simbol kekuasaan dan dominasi dalam demokrasi dinetralisir oleh dimensi etis yang diintrodusir melalui kebenaran prosedural suara terbanyak (mayoritas). Nilai kebenaran dan keadilan menjadi diukur berdasarkan pandangan kuantitatif. Realitas menunjukan bahwa seringkali unsur kepentingan-kepentingan golongan atau kelompok tertentu yang berada di balik kebenaran prosedural formal suara terbanyak tersebut. Kegiatan berpolitik dalam demokrasi dalam tataran tertentu dapat cenderung mengabaikan etika. Bandingkan Hendra Nurtjahjo, Filsafat Demokrasi, Bumi Aksara, Jakarta, 2005, hlm. 88 dan 93. Nilai moral demokrasi merupakan merupakan ajaran 
Sumber daya yang dimiliki oleh partai politik akan senantiasa bertambah melalui sumbangan dari korporasi. Partai politik diharapkan bekerja lebih maksimal sebagai fasilitator dalam memperjuangkan aspirasi seluruh kepentingan rakyat. ${ }^{36}$ Jaringan konseptual relasi oposisi makna dalam model semiotic square dapat dirumuskan ke dalam empat term sebagai oposisi dasar sekaligus relasi dan operasi dasarnya. Visualisasi relasi oposisional makna sumbangan korporasi pada partai politik dapat disajikan dalam Ragaan 5.

\section{Ragaan 5 \\ Makna Sumbangan yang Berasal dari Korporasi pada Partai Politik dalam Model Semiotic Square}

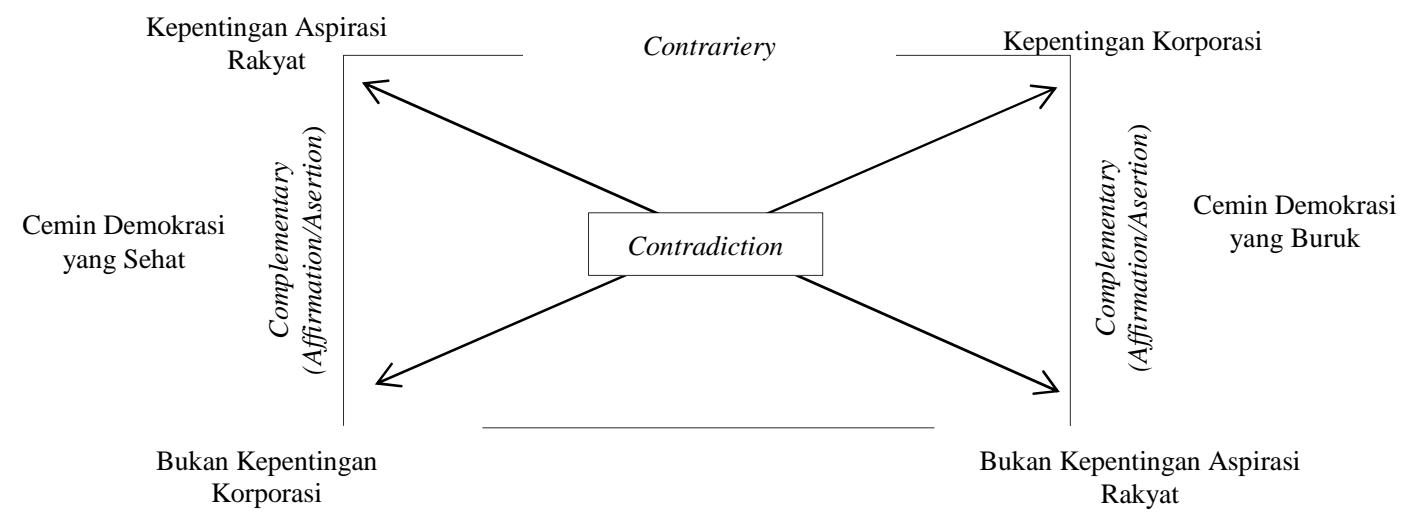

Sumbu operasi contradiction ditunjukkan melalui kepentingan aspirasi rakyat dengan bukan kepentingan aspirasi rakyat. Sebaliknya merupakan kepentingan korporasi dengan bukan kepentingan korporasi. Sumbu operasi affirmation/assertion ditunjukan jika sumbangan yang berasal dari korporasi digunakan untuk memperkuat dan memaksimalkan kekuatan partai dalam tujuan untuk memperjuangkan kepentingan aspirasi rakyat dan bukan untuk kepentingan korporasi. Situasi ini mencerminkan proses demokrasi yang sehat. Sebaliknya jika sumbangan yang berasal dari korporasi digunakan untuk kepentingan korporasi dan menjadi media investasi politik untuk menuntut imbalan, maka mencerminkan proses demokrasi yang tidak sehat.

demokrasi yang disandarkan pada prinsip-prinsip etika yang mengacu pada martabat kehidupan manusia sehingga proses demokrasi dapat dipertanggungjawabkan secara rasional dan bermoral.

36 Tim Peneliti, Penelitian Hukum Tentang Akuntabilitas Pendanaan Parpol dalam Undang-Undang Nomor 2 Tahun 2011, Badan Pembinaan Hukum Nasional, Kementerian Hukum dan HAM RI. Tahun 2014. 
Sumbu relasi contrariery diformulasikan, jika sumbangan yang berasal dari korporasi digunakan untuk memperkuat dan memaksimalkan kekuatan partai dalam tujuan memperjuangkan kepentingan aspirasi rakyat, dan berkemungkinan dimanfaatkan untuk kepentingan korporasi sebagai media investasi politik (menuntut imbalan). Apabila formulasi ini terjadi, maka mendesak dilakukannya evaluasi terhadap penegakan hukum atas transparasi dan akuntabilitas keuangan partai politik yang selama ini belum berjalan maksimal.

Makna yang beroperasi di balik kata "sumbangan" dalam teks norma hukum positif dapat menyajikan jaringan konseptual relasi oposisi makna. Di satu sisi sumbangan yang berasal dari korporasi ditujukan untuk membangun dan memaksimalkan kekuatan partai politik dalam rangka memperjuangkan aspirasi kepentingan rakyat. Di sisi lain sumbangan ini mendapatkan relasi oposisi makna yaitu membuka ruang relasi yang lebar dengan kepentingan dan sifat dasar korporasi yang profit oriented.

Kooptasi dan komersialisasi partai politik berpotensi dapat terjadi. Terjalin relasi kompleks antara kekuasaan yang menjadi tujuan partai politik dan strategi korporasi untuk mengakumulasi kapital. ${ }^{37}$ Situasi ini terdukung oleh penegakan hukum dari serangkaian peraturan perundang-undangan yang diidentifikasi masih belum berjalan secara efektif. Kontestasi politik yang membutuhkan biaya tinggi dalam proses demokrasi dapat dimanfaatkan oleh para korporasi. ${ }^{38}$

Korporasi memanfaatkan sumber daya modal yang dimilikinya untuk berinvestasi melalui kegiatan politik. ${ }^{39}$ Kata "sumbangan" yang memiliki makna konotasi positif dapat menjadi simbol efektif untuk menyembunyikan kepentingan yang ada di baliknya. Disadari atau tidak keberadaan teks norma hukum positif

${ }^{37}$ Ayn Rand meyampaikan bahwa terdapat tiga sistem nilai dalam ideologi kapitalisme yaitu, kebebasan individu, kepentingan diri, dan mekanisme pasar/pasar bebas. Nilai yang mendasari ide dasar kebebasan individu selain pengakuan mengenai hak milik termasuk kebebasan untuk berkompetisi. Ayn Rand, Nathaniel Branden, Alan Grespan, Robert Hessen, The Capitalism: Unknown Ideal, 1986. Aturan main dalam demokrasi meyediakan cukup peluang bagi kepentingan-kepentingan gerakan-gerakan alternatif untuk meraih akses terhadap kursi kekuasaan. Lihat James Petras dan Henry Veltmeyer, Globalization Unmasked: Imperialisme the 21 Century, Zed Book Ltd, London, 2001. Terjemahan Agung Prihantoro, Menelanjangi Globalisasi: Sepak Terjang Imperialism Abad 21, Kreasi Wacana, Bantul, 2014, hlm. 196.

38 "This symbiosis between politicians, bureaucrats and entrepreneurs/managers has blurred the distinction between public and private domains and laid the foundation for illicit practices of political finance". Lihat Elin Falguera, Samuel Jones, Magnus Ohman (ed), Funding of Political Parties and Election Campaigns: A Handbook on Political Finance', International Institute for Democracy and Electoral Assistance, Stockholm-Sweden, 2014, hlm. 86.

${ }^{39}$ Bentuk manipulatif yang dapat dilakukan baik itu oleh korporasi milik warga negara Indonesia (domestik) atau Korporasi milik asing. 
tersebut dapat dijadikan media yang efektif untuk menyusupkan kepentingan korporasi. Melalui sumbangan yang telah diberikan memungkinkan korporasi untuk menuntut imbalan pada partai politik.

Persaingan pasar dalam kegiatan usaha tentu akan terus berlangsung semakin ketat. Kompetisi akan memunculkan inovasi. Produk (barang dan jasa) yang lebih bervariasi hadir dan bermuara pada pasar yang kompetitif. Tanda-tanda hegemonik kapitalisme memang muncul melalui proses identifikasi dan interaksi yang kompleks. ${ }^{40}$ Korporasi harus terus melakukan strategi, improvisasi, dan penguatan di seluruh aspek internal maupun eksternal apabila ingin memenangkan persaingan pasar. Faktor eksternal merupakan faktor yang tidak dapat diabaikan. Dukungan politik dapat menjadi salah satu bagian penting dari faktor eksternal tersebut.

Sumbangan kepada partai politik dapat menjadi strategi alternatif yang rasional bagi korporasi untuk mengambil manfaatnya dikemudian hari. Aktoraktor partai yang memenangkan kontestasi politik dan mengisi ruang-ruang institusi kekuasaan dalam bentuknya yang ekstrim dapat menjadi fasilitator kepentingan korporasi. Aktor-aktor partai yang kondisikan untuk memberikan berbagai akses kemudahan bagi korporasi dalam rangka memenangkan persaingan pasar.

Partai politik tentu tidak diperkenankan menerima sumbangan dana kampanye melebihi batas jumlah maksimal yang telah ditentukan. Bukan hal yang tidak mungkin korporasi bersama aktor partai politik bersepakat untuk menggunakan perusahan-perusahaan fiktif. Padahal sumber dana yang sesungguhnya berasal dari korporasi yang sama. Pada masa kampanye sumbangan dapat dialirkan melalui tim-tim kampanye informal. Sehingga batas jumlah sumbangan dapat melebihi dari yang seharusnya. Penelusuran atas sumber dan jumlah keuangan akan lebih sulit terdetekti. ${ }^{41}$ Strategi-strategi manipulatif ini pasti akan terus berkembang dalam bentuk yang lebih bervariasi.

\footnotetext{
${ }^{40}$ Lihat Martijn Konings, Emotional Logic of Capitalism: What Progessives Have Missed, Stanford University Press, California, 2015, hlm. 25.

${ }^{41}$ Bandingkan Bruno Wilhelm, Money in Politics: Sound Political Competition and Trust in Government, OECD, New York-Paris, 2013, hlm. 35
} 
Demokrasi liberal dalam nuansa kapitalisme menciptakan kultur yang bersifat materialistik. Fredric Jameson menyampaikan bahwa,

"...Capitalism, and the modern age, is a period in which, with the extinction of the sacred and the "spiritual," the deep underlying materiality of all things has finally risen dripping and convulsive into the light of day; and it is clear that culture itself is one of those things whose fundamental materiality is now for us not merely evident but quite inescapable. This has, however, also been a historical lesson: it is because culture has become material that we are now in a position to understand that it always was material, or materialistic, in its structures and functions...". 42

Kepentingan mengakumulasi kapital merupakan tujuan korporasi sekaligus menjadi sifat dasarnya yang akan berlangsung terus-menerus tanpa batas. Korporasi tidak akan berhenti mengejar apa yang menjadi objek hasratnya karena memang untuk itulah dia dibentuk. ${ }^{43}$ Korporasi-korporasi tentu menginginkan dukungan politik dan kebijakan untuk terus memberikan akses kemudahan dan melanggengkan keuntungan yang diperoleh. Bukan hal yang tidak mungkin apabila korporasi memanfaatkan media partai politik untuk memengaruhi kebijakan ekonomi.

Korporasi-korporasi membutuhkan mekanisme kekuasaan untuk mendukung kepentingannya. Hubungan simbiosis mutualisme antara korporasi dengan partai politik mengarahkan institusi kekuasaan sebagai aktor pelengkap dalam rangka menggulirkan ambisi para kapitalis. Upaya ini salah satunya dapat ditempuh melalui aktor-aktor partai politik yang masuk pada institusi kekuasaan (hukum). Tindakan ini memungkinkan produk hukum dimanipulasi untuk kepentingan korporasi. Modus operandi ideologis yang bergerak menggunakan organisasi dan legalitas aturan sebagai rasionalisasi. Proses demokrasi dapat menjadi sarana kepentingan modal yang terorganisasi. Regulasi yang muncul akhirnya hanya berpihak pada sifat dasar korporasi dan mencederai nilai-nilai keadilan di masyarakat. Teks norma hukum positif menjadi komoditas yang memiliki nilai tukar (exchange value) menguntungkan korporasi.

${ }^{42}$ Fredric Jameson Postmodernism , or, The Cultural Logic of Late Capitalism, Duke University Press, United States of America, 1991, hlm. 67.

43 Lihat J.F Lyotard, Libidinal Econopmy, The Athlone Press, London, 1993, hlm. 64. dan Jean Baudrillard, Fatal Srategies, Pluto Press, London, 1990, hlm. 9. 
Hasil kebijakan yang hanya berpihak pada kepentingan korporasi untuk mengakumulasi kapital beberapa diantaranya telah dinyatakan bertentangan dengan UUD NRI 1945.44 Sumbangan yang berasal dari korporasi tentu dapat berkontribusi positif apabila mampu menjelma sesuai dengan tujuan yang sesunggunya. Ketika sumbangan korporasi yang didasarkan pada makna nilai kejujuran, sukarela, keadilan, terbuka, tanggung jawab, kedaulatan, kemandirian, dan menunjung tinggi hukum tidak pernah terwujud dalam kenyataan, maka berpotensi menjadi media yang terus dinikmati oleh korporasi. ${ }^{45}$ Sumber keuangan partai politik yang salah satunya berasal dari korporasi dapat menjadi pintu masuk dan membuka ruang bagi sifat dasar korporasi untuk terus bermain di dalamnya.

Transparansi dan akuntabilitas sumber keuangan partai politik yang menjadi salah satu cermin sehatnya proses demokrasi, dapat menjadi konsep kebenaran hukum yang diyakini kebenarannya tetapi sulit dibuktikan keterlaksanaannya. Pertanggungan jawaban sumber keuangan partai politik hanya menjadi kata dan frasa kiasan yang terdapat dalam serangkaian teks norma hukum positif. ${ }^{46}$

${ }^{44}$ Hasil kebijakan yang tidak mencerminkan nilai, ideologis, konstitutif, sekaligus sosiologis dari bangsa Indonesia dan sarat muatan kepentingan korporasi untuk mengakumulasi kapital. Beberapa undang-undang oleh Mahkamah Konstitusi Republik Indonesia dinyatakan bertentangan dengan UUD NRI 1945 dan dinyatakan tidak mempunyai kekuatan hukum yang mengikat. Undang-undang tersebut diantaranya adalah, Undang-Undang No. 20 Tahun 2002 tentang Ketenagalistrikan (Putusan MK No. 001-021-022/PUU-I/2003), Undang-Undang No. 7 Tahun 2004 tantang Sumber Daya Air (Putusan MK No. 85/PUU-XII/2013), Undang-Undang No. 77 Tahun 2012 tentang Perkoperasian (Putusan MK No. 28/PUU-XI/2013). Piliang menyampaikan bahwa perkembangan kapitalisme menuju ke arah libidonomics, yaitu sistem ekonomi yang di dalamnya terjadi eksplorasi ekstrem segala potensi libido sebagai komoditas dalam rangka mendapatkan keuntungan maksimal (added values). Ideologi libidonomi kapitalisme menjadikan tubuh segala potensi libidonya sebagai titik sentral dalam produksi dan reproduksi ekonomi serta pembiakan ekonomi. Yasraf Amir Piliang, Posrealitas: Realitas Kebudayaan dalam Era Posmetafisika, Jalasutra, Yogyakarta \& Bandung, 2004, hlm. 379. Lihat Poulantzas, Political Power and Social Clasess, New Left Book, London, 1973, hlm. 128-129. Serangkaian undang-undang teridentifikasi begitu sarat muatan kepentingan korporasi yang merupakan produk dari hasil demokrasi yang bernuansa kapitalisme.

${ }^{45}$ Lihat Pasal 39 ayat (1) Undang-Undang No. 2 Tahun 2011 tentang Partai Politik. Iklim demokrasi yang bernuansa kapitalisme akan memberikan tantangan berat bagi akses transparansi dan akuntabilitas sumber-sumber keuangan partai politik walaupun telah diatur sedemikian ketat.

46 Pengaturan pertanggungjawaban keuangan partai dapat dilihat dalam Pasal 34 A ayat (1), (2), (3), Pasal 39 ayat (1), (2), (3), Pasal 47 Undang-Undang No. 2 Tahun 2011 tentang Partai Politik. Pengaturan dana kampanye dapat dilihat dalam Pasal 329 sampai dengan Pasal 339 Undang-Undang No. 7 Tahun 2017 tentang Pemilihan Umum. Pasal 16 Peraturan Pemerintah No. 1 Tahun 2018 tentang Bantuan Keuangan pada Partai Politik. Keputusan Komisi Pemilihan Umum Republik Indonesia No. 247 Tahun 2018 tentang Pedoman Pelaksanaan Audit Laporan Dana Kampanye Peseta Pemilihan Gubernur, dan Wakil Gubernur, Bupati dan Wakil Bupati, dan/atau Walikota dan Wakil Wali Kota. Peraturan Komisi Pemilihan Umum Republik Indonesia No. 5 tahun 2017 tentang Peraturan Dana Kampanye Peserta Pemilihan Gubernur dan Wakil Gubernur Bupati dan Wakil Bupati, dan/atau Walikota dan Wakil Wali Kota. Berdasarkan masukan dari Akuntan Publik, KPU pernah menerbitkan lima buku seri tentang audit dana kampanye pemilu diantaranya, Komisi Pemilihan Umum, "Petunjuk Pelaksanaan Tata Administrasi Keuangan Partai Politik dan Peserta Pemilu”, Seri Publikasi Nomor 14.1 Tahun 2003. Komisi Pemilihan Umum, Pedoman Sistem Akuntansi Keuangan Partai Politik, Seri Publikasi Nomor 14.2 Tahun 2003. Komisi Pemilihan Umum, Pedoman Pelaporan dan Kampanye Peserta Pemilu", Seri Publikasi 
Pernyataan satire ${ }^{47}$ untuk mempertanyakan, menuntut, dan menggugah kesadaran seluruh elemen terkait, bahwa nilai-nilai yang terkandung di balik serangkaian teks norma hukum positif belum benar-benar terwujud. ${ }^{48}$

Model semiotic square pada tataran konseptual dapat menunjukan relasi konseptual oposisi makna yang beroperasi di balik teks norma hukum positif. Sumbangan dari korporasi dapat menyajikan makna yang bersifat destruktif. Berpotensi dimanfaatkan untuk memengaruhi kebijakan ekonomi yang hanya berpihak pada korporasi. Korporasi dapat menuntut regulasi yang hanya melindungi, memudahkan, dan menguntungkan kegiatan korporasi. Arena investasi bagi korporasi untuk meminta kemudahan perizinan, proyek/tender, sarana korupsi, dan menciptakan ketidakadilan di masyarakat. Partai politik pada akhirnya tidak memiliki kedaulatan, kemandirian, dan integritas.

Dimensi kecurigaan yang mewarnai kajian ini tentu harus ditempatkan dalam kerangka intensitas kewaspadaan, tanpa mengabaikan dampak positif sumbangan yang berasal dari korporasi. Pewaspadaan dilakukan untuk mengidentifikasi dan mengantisipasi berbagai produk hukum yang telah atau berpotensi dimanfaatkan oleh kepentingan-kepentingan tertentu. Upaya ini sekaligus sebagai daya dorong untuk terus melakukan perbaikan dan penyempurnaan yang sistematis dalam pembentukan dan penegakan hukum yang konkret.

\footnotetext{
Nomor 14.3 Tahun 2003. Komisi Pemilihan Umum, "Suplemen Pedoman Sistem Akuntansi Keuangan Partai Politik: Simulasi Penyusunan Laporan Keuangan Partai Politik, Seri Publikasi Nomor 14.4 Tahun 2003, Komisi Pemilihan Umum, Suplemen Pedoman Pelaporan Dana Kampanye Peserta Pemilu: Simulasi Penyusunan Laporan Dana Kampanye Peserta Pemilu, Seri Publikasi Nomor 14.5 Tahun 2003.

Praktik penyalahgunaan dana publik secara transparan dan akuntabel oleh partai politik tidak hanya terjadi di Indonesia tetapi terjadi juga di negara Tahiland, Filipina, meksiko dan Brazil, Jepang, Taiwan, India, dan negaranegara demokrasi lainnya. Lihat Tim Riset Institute For Stategic Initiatives (ISI), Penggunaan Dana Publik. untuk Kampanye, Hasil Penelitian Tim Riset InstituteFor Stategic Initiatives (ISI) bekerjasama dengan Kemitraan Patnership dan Perludem, Jakarta, 2014, hlm. 7. Mulai dari daftar penyumbang, rekening kas, neraca, laporan realisasi atau penggunaan anggaran, serta kas pemasukan dan pengeluaran keuangan telah diatur. Namun demikian pelaksanaan atas prinsip akuntabilitas dan transparansinya tersimpan rapat di tengah muara hasrat kekuasaan dan akumulasi kapital.

47 Satire adalah gaya bahasa yang menyatakan sindiran berisi kritik terhadap suatu keadaan. Penggabungan antara unsur ironi dan sarkasme. Baca Rendy Pahrun Wadipalapa, "Meme Culture \& Komedi-Satire Politik: Kontestasi Pemilihan Presiden dalam Media Baru”, Jurnal Imu Komunikasi, Vol. 12, No. 1, Juni 20018, hlm. 7. Baca Johnny E. Miles, Wise King-Royal Fool: Semiotics, Satire and Proverbs 1-9, T\&T Clark International, London-New York, 2004, hlm. 29-30.

48 Partai Politik dan Korporasi itu sendiri, Pemerintah, Komisi Pemilihan Umum (KPU), Badan Pengawas Pemilu (BAWASLU), Pusat Pelaporan dan Analisis Transaksi Keuangan (PPATK), Komisi Pemberantasan Korupsi (KPK), Badan Pemeriksa Keuangan (BPK), masyarakat umum, dan seluruh elemen lain yang terlibat dalam kegiatan demokrasi.
} 
Beragam regulasi yang mengatur tentang transparansi dan akuntabilitas pertanggungjawaban keuangan partai tentu tidak akan berjalan dengan optimal tanpa diiringi penegakan hukum yang nyata dan konsisten. Mempertimbangkan agar KPU lebih berkonsentrasi untuk terus melakukan perbaikan dalam proses penyelenggaraan PEMILU. Mencermati beban kerja KPU yang relatif berat serta kinerja BAWASLU yang kurang optimal. Layak dipertimbangkan wacana dihadirkannya regulasi dan lembaga khusus yang bertugas melakukan penegakan hukum berkaitan dengan sumber keuangan dan dana kampanye partai politik.

Lembaga independen yang bebas dari konflik kepentingan. Lembaga yang dihadirkan dalam kewenangan terbatas untuk mengelola sistem pelaporan sumber keuangan dan dana kampanye. Lembaga yang bertugas memverifikasi, mengivestigasi, mengungkap (mengumumkan), melakukan penuntutan pelanggaran, memberikan sanksi, dan seterusnya. Diiringi oleh penyempurnaan koordinasi antar kelembagaan terkait dengan KPU, BAWASLU, PPATK, BPK, dan KPK. Gagasan ini tentu harus melalui pengkajian yang mendalam. Singkronisasi regulasi untuk menghindarkan tumpah tindih kewenangan antar lembaga dan penyiapan infrastruktur kelembagaan yang matang.

\section{Penutup}

Aplikasi model semiotic square pada Pasal 35 ayat (1) huruf c Undang-Undang Nomor 2 Tahun 2011 tentang Partai Politik menunjukan bahwa kata 'sumbangan' korporasi pada partai politik menghadirkan relasi konseptual oposisi makna. Peran serta korporasi dalam proses demokrasi melalui sumbangan yang diberikan pada partai politik, pada prinsipnya ditujukan untuk memaksimalkan kekuatan partai dalam memperjuangkan aspirasi kepentingan rakyat. Di saat bersamaan berelasi dengan sifat dasar korporasi yang kepentingan utamanya memaksimalkan perolehan laba. Kata 'sumbangan' yang terdapat dalam teks norma hukum positif tersebut dapat dijadikan sarana efektif (pintu masuk) oleh korporasi untuk bermanufer dan mengambil keuntungan. Akibatnya proses demokrasi yang tampil menjadi tidak sehat dan terjebak dalam hegemoni ideologi kapitalisme yang mendegradasi nilai-nilai keadilan. 
Sehubungan dengan hasil kajian pemaknaan di atas, maka diperlukan medium yang dapat menetralisir relasi oposisi makna yang muncul pada tataran konseptual, sekaligus efektif dalam mengantisipasi dan menanggulangi beragam pelanggaran pada tataran praktik. Mencermati besarnya potensi distorsi yang akan mengganggu sehatnya proses demokrasi dan akumulasi dampak negatif yang dapat mencederai nilai-nilai keadilan di masyarakat. Tampaknya tidak berlebihan dan layak dipertimbangkan apabila medium tersebut diwujudkan dalam bentuk lembaga khusus. Lembaga khusus yang diberikan kewenangan terbatas dalam mengelola sistem pelaporan sumber keuangan dan dana kampanye partai politik, termasuk melakukan penegakan hukum atas pelanggaran yang terjadi.

\section{Daftar Pustaka}

\section{Buku}

Adams, Ian, Political Ideology Today, Manchester University Press, Manchester, 1993, terjemahan Ali Noerzaman, Ideologi Politik Mutakhir: Konsep, Ragam, Kritik, dan Masa Depannya, Qalam, Yogyakarta, 2004.

Baudrillard, Jean, Fatal Srategies, Pluto Press, London, 1990.

Beetham, David dan Kevin Boyle, Introducing Democracy:80 QuestionseAnswers, terjemahan. Bern Hidayat, Demokrasi: 80 Tanya Jawab, Kanisius, Yogyakarta, 1995.

Bochenski, J. M., The Method of Comtemporary Thought, translate by Peter Caws, Springer, Netherlands, 1965.

Budiyanto, Irmayanti M., Realitas dan Objektivitas: Refleksi Kritis Atas Cara Kerja Ilmiah, Wedya Sastra, Jakarta, 2002.

Broekman, Jan M. and Lary Cata Backer, Lawyers Making Meaning The Semiotics of Law in Legal Education II, Springer Dordrecht Heidelberg, LondonNewYork, 2013.

ed), Signs In Law - A SourceBook The Semiotics of Law in Legal Education III, Heidelberg Springer International Publishing Switzerland, New YorkLondon, 2015.

Cahyadi, Antonisus, Hukum sebagai Teks:Penanda yang Kosong, dalam Antonisus Cahyadi dan Donny Danardono (ed), Sosiologi Hukum dalam Perubahan, Obor Indonesia Press, Jakarta, 2009.

Chandler, Daniel, Semiotics: The Basic, Second edition, Routledge, London and New York, 2007.

Denzim, Norman K. and Yvonna S. Lincoln, Introduction The Discipline and Practice of Qualitative Research, Dalam Norman K. Denzim and Yvonna S. Lincoln, 
ed., The SAGE Handbook of Qualitative Research: Fifth Edition, Sage Publication, London 2018.

Falguera, Elin, Samuel Jones, Magnus Ohman (ed), Funding of Political Parties and Election Campaigns: A Handbook on Political Finance, International Institute for Democracy and Electoral Assistance, Stockholm-Sweden, 2014.

Greimas, A. J. and J. Courtés, Semiotics and Language: An Analytical Dictionary, trans. Larry Crist, Daniel Patte, James Lee, Edward McMahon II, Gary Phillips, and Michael Rengstorf, Indiana University Press, Bloomington, 1982.

Jameson, Fredric, Postmodernism, or, The Cultural Logic of Late Capitalism, Duke University Press, United States of America, 1991.

Kaelan, M.S, Metode Penelitian Kualitatif Bidang Filsafat; Paradigma bagi Pengembangan Penelitian Interdisipliner Bidang Filsafat, Budaya, Semiotika, Sastra, Hukum, dan Seni, Paradigma,Yogyakarta, 2005.

Peter Mahmud Marzuki, Penelitian Hukum, Kencana Penadamedia Group, Jakarta, 2005.

Kevelson, Roberta (ed), Law and Semiotics Volume 1, Plenum Press, New York and London, 1987. , Roberta, The Law as a System of Signs, New York, Plenum Press, 1988.

Konings, Martijn, Emotional Logic of Capitalism: What Progessives Have Missed, California, Stanford University Press, 2015.

Louis, Hebert, Tool for Texts and Image Analysis An Introduction to Applied Semiotics, trans. Julie Tabler, Departement de Letter Universitie du Quebec, 2018.

Lyotard, J.F, Libidinal Economy, London, The Athlone Press, 1993.

Mangesti, Yovita A. dan Bernard L Tanya, Moralitas Hukum, Genta Publishing, Bantul-Yogyakarta, 2014.

Martin, Bronwen and Felizitas Ringham, Dictionary of Semiotics, Cassel, London and New York, 2000.

Noth, Winfried, Handbook of Semiotic, Indiana University Press, Bloominton \& Indianapolis, 1990.

Nurtjahjo, Hendra, Filsafat Demokrasi, Bumi Aksara, Jakarta, 2005.

Petras, James dan Henry Veltmeyer, Globalization Unmasked: Imperialisme the 21 Century, London, Zed Book Ltd, 2001. Terjemahan Agung Prihantoro, Menelanjangi Globalisasi: Sepak terjang Imperialism Abad 21, Kreasi Wacana, Kasihan Bantul, 2001.

Rand, Ayn, Nathaniel Branden, Alan Grespan, Robert Hessen, The Capitalism: Unknown Ideal, 1986.

Ronald Schleifer, A.J Greimas and The Nature Meaning: Lingustics, Semiotics, and Discourse theory, Croom Helm-Roudledge, Australia, 1987. 
Scholten, Paul, De Structuur Der Rechtswetenschap,Konninklijke Nederlansche Akademie, Van Wetenschappen, Afdeeling Letterkunde, 17 Maret 1942. Terjemahan. B. Arief Sidharta, Struktur Ilmu Hukum, Alumni, Bandung, 2013.

Shidarta, Hukum Penalaran dan Penalaran Hukum, Genta Publishing, Yogyakarta, 2013.

Sidharta, B. Arief, Refleksi tentang Struktur Ilmu Hukum: Sebuah Penelitian tentang Fundasi Kefilsafatan dan Sifat Keilmuan Ilmu Hukum sebagai Landasan Pengembangan Ilmu Hukum Nasional Indonesia, Mandar Maju, Bandung, 2000.

Sobur, Alex, Analisis Teks Media, Remaja Rosdakarya, Bandung, 2004.

Soerjono Soekamto dan Sri Mamuji, Penelitian Hukum Normatif: Suatu Tinjauan Singkat, Raja Gravindo Persada, Jakarta, 1995.

Sudjito, Ilmu Hukum Holistik: Studi untuk Memahami Kompleksitas, dan Pengaturan Pengelolaan Irigasi, Gadjah Mada University Press, Yogyakarta, 2014.

Suhud, Rofik, Ekspresi Politik Muslim, Mizan, Bandung, 1998.

Susanto, Anthon F., Dekonstruksi Hukum: Eksplorasi Teks dan Model Pembacaan, Genta Publishing, Yogyakarta, 2010.

Syamsudin, M., Konstruksi Budaya Hukum: Berbasis Hukum Progesif, Kencana Prenada Media Group, Jakarta, 2012.

Wignjosoebroto, Soetandyo, Hukum, Paradigma, Metode dan Dinamika Masalahnya, ELSAM dan HUMA Press, Jakarta, 2002.

Williams, Malcolm and Tim May, Introduction to The Philosophy of Social Research, UCL Press, London, 1996.

Miles. Johnny E., Wise King-Royal Fool: Semiotics, Satire and Proverbs 1-9, T\&T Clark International, London-New York, 2004.

\section{Desertasi/Hasil Penelitian}

Steeman, Theodore M., Religious and National Integration, Desertation, Harvard University, 1973.

Tim Peneliti, Penelitian Hukum Tentang Akuntabilitas Pendanaan Parpol Dalam Undang-Undang Nomor 2 Tahun 2011, Laporan Penelitian, Badan Pembinaan Hukum Nasional, Kementrian Hukum dan HAM RI. Tahun 2014.

Tim Riset Institute For Stategic Initiatives (ISI), Penggunaan Dana Publik untuk Kampanye, Laporan Penelitian, Institute For Stategic Initiatives (ISI) bekerjasama dengan Kemitraan Patnership dan Perludem, Jakarta, tanpa tahun.

\section{Jurnal}

Cacciaguidi, Sophie, Fahy, Annabelle Mooney, The Promise of Legal Semiotics", International Journal Semiotics of Law, Springer, Agustus 2009. 
Kavelson, Roberta, "Semiotics and Methods of Legal Inquiry: Interpretation and Discovery in Law from the Perspective of Peirce's Speculative Rhetoric", Indiana Journal Law, Vol. 61: Iss. 3, Article 3, Indiana University, Indiana, 1986.

Lukman, Marcus, "Semiotika Reformasi Hukum Res Republika, Res Konstitusi, dan Res Ketuhanan", Pusat Pengkajian Hukum dan Pembangunan, Jurnal Perpektif ,Vol. 3, No. 3, edisi Juli, Tahun 1998.

Manurung, Torang Rudolf Efendi, "Perkembangan Politik Hukum Pertanggungjawaban Partai Politik dalam Bantuan Pengelolaan Bantuan Negara Pasca Reformasi", Jurnal Yustisia, Vol.19, Januari-April, 2015.

Rendy Pahrun Wadipalapa, "Meme Culture \& Komedi-Satire Politik: Kontestasi Pemilihan Presiden dalam Media Baru", Jurnal Ilmu Komunikasi, Vol. 12, No. 1, Juni 2018.

Suharyo, Surono, Mujid F. Amin, “Bahasa dan Kekuasaan: Antara Pertarungan Wacana dan Perebutan Kekuasaan (Studi Kasus Perilaku Politisi di Media Massa)", Jurnal HUMANIKA, Vol. 19 No.1, Fakultas Ilmu Budaya Universitas Diponegoro Semarang, 2014.

Verenich, Vadim, "The Semiotic Model of Legal Reasoning”, International Journal of Law Language E Discourse, IJJLD, 2012.

\section{Makalah}

Background Papper, "Money in Politics: Sound Political Competition and Trust in Government", OECD, New York-Paris, 2013.

Said, Ihkwan M., "Perspektif Masalah Kebahasaan Bahasa Indonesia di Bidang Hukum, Makalah Proseding", Seminar Bersama UNHAS, Makasar, 6-8 November, 2006.

Wignjosoebroto, Soetandyo, "Konsep Hukum dan Ilmu Sosial: Perbedaan Ancangan Konsepsional dan Konsekuensi Metodenya,", Makalah Penalaran Metodologi Penelitian Hukum di Fakultas Hukum Universitas Hasanuddin, Makasar, Februari 1994.

\section{Internet}

https:/ / kbbi.web.id, Diakses 27 Juli 2018.

\section{Peraturan perundang-Undangan}

Undang-undang Republik Indonesia Nomor 2 Tahun 2011 tentang Partai Politik, Lembaran Negara Republik Indonesia Tahun 2011 Nomor 8, Tambahan Lembaran Negara Republik Indonesia Nomor 5189.

Undang-Undang No. 7 Tahun 2017 tentang Pemilihan Umum, Lembaran Negara Republik Indonesia Tahun 2017 Nomor 182, Tambahan Lembaran Negara Republik Indonesia Nomor 6109. 
Peraturan Pemerintah Nomor 1 Tahun 2018 tentang Bantuan Keuangan pada Partai Politik

Peraturan Komisi Pemilihan Umum Republik Indonesia Nomor 5 Tahun 2017 tentang Peraturan Dana Kampanye Peserta Pemilihan Gubernur dan Wakil Gubernur Bupati dan Wakil Bupati, dan/atau Walikota dan Wakil Wali Kota.

Keputusan Komisi Pemilihan Umum Republik Indonesia Nomor 247 Tahun 2018 tentang Pedoman Pelaksanaan Audit Laporan Dana Kampanye Peseta Pemilihan Gubernur, dan Wakil Gubernur, Bupati dan Wakil Bupati, dan/atau Walikota dan Wakil Wali Kota.

\section{Putusan Pengadilan}

Putusan Mahkamah Konstitusi Nomor 001-021-022/PUU-I/2003 tentang Pengujian Undang-Undang No. 20 tahun 2002 tentang Ketenagalistrikan, 15 Desember 2004.

Putusan Mahkamah Konstitusi Nomor 85/PUU-XI/2013 tentang Pengujian Undang-Undang No. 7 Tahun 2004 Tentang Sumber Daya Air, 18 Februari 2015.

Putusan Mahkamah Konstitusi Nomor 28/PUU-XI/2013 tentang Pangujian Undang-Undang No. 17 tahun 2012 tentang Perkoperasian, 28 Mei 2014.

\section{Sumber Lain}

Komisi Pemilihan Umum, Petunjuk Pelaksanaan Tata Administrasi Keuangan Partai Politik dan Peserta Pemilu, Seri Publikasi Nomor 14.1 Tahun 2003.

Pedoman Sistem Akuntansi Keuangan Partai Politik, Seri Publikasi Nomor 14.2 Tahun 2003.

, Pedoman Pelaporan dan Kampanye Peserta Pemilu, Seri Publikasi Nomor 14.3 Tahun 2003.

Suplemen Pedoman Sistem Akuntansi Keuangan Partai Politik: Simulasi Penyusunan Laporan Keuangan Partai Politik", Seri Publikasi Nomor 14.4 Tahun 2003.

Suplemen Pedoman Pelaporan Dana Kampanye Peserta Pemilu: Simulasi Penyusunan Laporan Dana Kampanye Peserta Pemilu", Seri Publikasi Nomor 14.5 Tahun 2003. 